$\mathbf{R}_{\text {ESEARCH }} \mathbf{P}_{\text {APER }} \longrightarrow \frac{\text { FOOD SCIENCE }}{\text { RESEARCH JOURNAL }}$

e ISSN-2230-9403 - Visit us : www.researchjournal.co.in RESEARCH JOURNAL

DOI : $10.15740 / \mathrm{HAS} / F S R J / 8.2 / 173-179$

\title{
Development and shelf-life study of the deep fat fried bengal gram flakes
}

\author{
Himani SRivastava And Kirti Kumari
}

Bengal gram is a major pulse crop in India, widely grown for centuries and accounts for nearly 40 per cent of the total pulse production. The present investigation deals with the development of Bengal gram flakes. The flakes was prepared by soaking the Bengal gram for 12 hours and then sun dried for 2 hours later on it was pressed and rolled with the help of heavy weight roller $(10 \mathrm{~kg})$. Physical study before and after flaking revealed that length, breadth and thickness were changed from 0.91 to $1.49 \mathrm{~cm}, 0.70$ to $0.25 \mathrm{~cm}$ and 0.72 to $0.25 \mathrm{~cm}$, respectively. Samples were evaluated initially and after at the intervals 30, 60 and 90 days for sensory and physico-chemical analysis. Moisture content was increased from 1.20\% to $2.92 \%$ from 0 day to 90 days of storage period. There was no change in ash content. Fat content was recorded as 24.39 to $24.38 \%$ from 0 days to 90 days. Protein was recorded as 21.86 to $21.81 \%$ and peroxide value was increased from 0.55 to $4.1 \mathrm{meq} / \mathrm{kg}$ from 0 to 90 days of storage period. Sensory results show that products of acceptable quality can be prepared. This study indicates the feasibility of developing such nutritious products.

Key Words : Flaking, Fried, LDPE, Physio-chemical changes, Shelf-life

How to cite this article : Srivastava, Himani and Kumari, Kirti (2017). Development and shelf-life study of the deep fat fried bengal gram flakes. Food Sci. Res. J., 8(2): 173-179, DOI : 10.15740/HAS/FSRJ/8.2/173-179.

Author for correspondence :

HIMANI SRIVASTAVA, Department of Processing and Food Engineering, College of Technology and Engineering, Maharana Pratap University of Agriculture and Technology, UDAIPUR (RAJASTHAN) INDIA

Email : himani037@gmail.com

Associate Authors' :

KIRTI KUMARI, Krishi Vigyan Kendra (UUHF) Ranichauri, TEHRI GARHWAL (UTTARAKHAND) INDIA 